\title{
Impact of stabilizers on the rheological properties of ice creams
}

\author{
Mariana Carniell MILLIATTI ${ }^{1}$, Suzana Caetano da Silva LANNES ${ }^{1 *}$
}

\begin{abstract}
The effect of the food hydrocolloids Guar gum, Locust bean gum (LBG) and Gelatin, as well as their mixtures (even carrageenan was used in all formulations $-0.035 \%$ ), was studied on the rheological characteristics of ice cream formulations. A frequency sweep test, at low temperature $\left(-8^{\circ} \mathrm{C}\right)$, was performed to evaluate the elastic $\left(G^{\prime}\right)$ and viscous $\left(G^{\prime \prime}\right)$ modulus. The ice cream produced using Gelatin and blend of Gelatin and LBG (0.09 and 0.18\%) presented higher values of G', which is an indicative of the presence of ice crystals and greater rigidity. The thermo-oscillatory rheometry was used to correlate the rheological properties and the characteristic of the ice creams (creaminess, sensory, melting). A temperature sweep test, from -10 to $5^{\circ} \mathrm{C}$ was performed to evaluate changes in the structures of the products and their relationship with the sensory properties. For all formulations tested, it was observed, from $-10{ }^{\circ} \mathrm{C}$ to $-1{ }^{\circ} \mathrm{C}$, a large decline in the elastic and viscous modulus due to the loss of interactions between the ice crystals, associated with their melting. After melting, the parameter G”, indicative of the creaminess of ice cream during consumption, showed a slight advantage to the ice creams produced with Guar gum alone and its blend with LBG.
\end{abstract}

Keywords: rheology; structure; hydrocolloids; gelatin; texture.

Practical Application: A few recent studies cite gelatin as potential stabilizer for ice cream, as in the past other hydrocolloids have replaced this. However, currently, the industries are producing differentiated and even specific gelatins (different technological process) for this type of application that deserve attention and research, providing gelatins with special qualities and specific particle size causing them to be used again as a functional ingredient in ice cream technology.

\section{Introduction}

The aerated structure of ice creams is stabilized by the combination of the fat network, ice crystals, stabilizing agents, emulsifiers, and the viscous matrix where they are all embedded in. Obviously, to obtain a high-quality product it is necessary to focus attention on other aspects of ice cream quality such number and size of ice crystals and fat globules, in addition to the rheological properties of the aqueous phase (Stanley et al., 1996).

The melting behavior of the ice creams is an indicative of the development of interactions between the various ingredients in the formulation and the existence of various structures of the final product. These factors contribute to the formation of the overall structure of the ice cream, not only during the freezing and beating process, but also during the storage temperature oscillations (Muse \& Hartel, 2004).

The ice cream structure determines some important sensory parameters such as stiffness, texture and melting resistance. The buildup of this structure starts with use of certain functional ingredients in ice cream formulation and the manufacturing process that includes heating, homogenizing, pasteurizing, aging, beating and freezing steps. The interaction between the different components of the ice cream makes even more difficult to predict the structural network of the ice creams evaluating each ingredient singly (Granger et al., 2005, Botega et al., 2013a, 2013b). The formulation including the selection of emulsifier and stabilizer/hydrocolloid as well as process used for producing (Rinaldi et al., 2014, Zhao et al., 2015, Kaleda et al., 2018).

The classic rheology begins with the consideration of two ideal materials: elastic solid and viscous liquid. The elastic solid is defined as the material which when deformed until a certain limit of external force returns to its original shape when the force is removed. Conversely, the viscous liquid has no defined shape and deforms irreversibly when a force is applied. Most food products present rheological properties between these two models and are termed viscoelastic (Adapa et al., 2000).

The determination of frozen products viscosity is not an easy task, but new techniques and methods have been used (Stanley et al., 1996). The development of efficient equipment capable of applying low and dynamic strains made it possible to obtain a better understanding of the viscoelastic behavior of foods stuffs. The small deformation of the oscillatory test is a useful tool for studying the microstructure of ice creams, due to its sensitivity to mechanical and thermal treatment (Winhab, 1993) while maintains the microstructure of the unstable sample during its measurements (Wildmoser et al., 2004).

Referring to analysis in oscillatory systems, one of the most important techniques is the analysis of linear viscoelastic systems, where an oscillating strain is applied to the sample and the resistance to the deformation is measured and proves to be 
independent of the strain. Generally, $10 \%$ is considered to be an ideal deformation for many products (Faria-Tischer, 2006).

The interaction between the particles of the sample under evaluation determines the system is elastic or viscous. Measurements of the modulus G' (storage modulus) and G' (loss modulus) as function of oscillatory frequency under a constant shear rate into the linear viscoelastic range, provide an understanding of these interactions (Faria-Tischer, 2006; Silva \& Lannes, 2011).

The rheological properties rendered by hydrocolloids in food systems are particularly important when applied in food formulations due to their effect on the texture and sensory attributes of the products. The rheological behavior of fluid or semi-solid food products should be watched carefully and considered for the proper modeling of the different processes followed in the Food Industry. Besides that, these characteristics are measured and evaluated as an indicator of the product quality (Bahramparvar et al., 2010).

The characterization of thermo-dependent rheological properties of ice cream is important to establish a relationship between structure and flow and to correlate physical parameters with sensory quality. The thermo-oscillatory rheology can be effectively used as a tool to have an idea about sensory quality of ice cream. In thermo-oscillatory rheometry the mechanical and thermal analyzes are coupled and thus it is possible to correlate the microstructure with the sensory attributes of the product.

The aim of this study was to investigate the rheological characteristics of ice creams produced using various stabilizers, used singly and in combination.

\section{Materials and methods}

\subsection{Formulations}

Six ice-cream formulations were prepared with: $8.5 \%$ of milk solids not fat, $10 \%$ of vegetable fat (low trans) - PRÓ LT 450 (Bunge, Brazil), 6.0\% of glucose syrup 42 (Corn Products, Brazil), and $0.88 \%$ of emulsifiers ( $0.85 \%$ Propylene glycol ester - PGMS 70-B- Grinsted ${ }^{\circledR}$ - Danisco, Brazil; 0.03\% Polysorbate 80 - ALKEST TW80 K, Oxiteno, Brazil). The stabilizers: k-carrageenan (Grinsted ${ }^{\circledR}$ CL 110, Danisco, Brazil), LBG (Grinsted ${ }^{\circledR}$ LBG 246, Danisco, Brazil), Guar Gum (Grinsted ${ }^{\circledR}$ GUAR 250, Danisco, Brazil) and Gelatin (Gelita ${ }^{\circledR}$ Gel Lac 130, Gelita, Brasil) were applied in six different combinations as presented in Table 1.

\subsection{The ice cream formulations were processed as follows:}

The water of the formulation was heated to $30^{\circ} \mathrm{C}$ in a pan and then the milk powder was added under stirring (Fisatom Stirrer, Mod. 713D, Brazil); At $40{ }^{\circ} \mathrm{C}$ the stabilizers, previously mixed with the sugar of the formula, were added to the reconstituted milk; The fat and glucose syrup were added at $45^{\circ} \mathrm{C}$; At $60^{\circ} \mathrm{C}$ the emulsifiers were finally added; The blends were pasteurized at $72^{\circ} \mathrm{C}$ for $10 \mathrm{~min}$ in the domestic stove; The blends were homogenized at $250 \mathrm{kgf} / \mathrm{cm} 2$ (Homogenizer Artepeças APLAB-10, Brazil); After homogenization, the blends were cooled to $4{ }^{\circ} \mathrm{C}$ in an ice bath and kept at that temperature in a refrigerator for 24 hours. The ice cream was processed (CONSERVEX / SKYSEN, Brazil). The temperature of the coolant bath in which the beating drum was immersed was about $-25^{\circ} \mathrm{C}$. The temperature of $-5^{\circ} \mathrm{C}$ was used as a signaling parameter of the end of the ice cream processing.

\subsection{Rheological measurements}

\section{Mixtures for ice creams}

The complex viscosity of the ice cream mix was determined by oscillatory tests. The tests were performed on a Haake MARS II rheometer (Thermo Electron Corporation, Germany), with a HAAKE Rheowin program (version 3.61), at $4{ }^{\circ} \mathrm{C}$. The cone-plate sensor (C35 / 1 Ti polished) with a $0.024 \mathrm{~mm}$ gap was used. Analyzes were performed at least in triplicate, with a stress amplitude sweep ranging from 0.01 to $100 \mathrm{~Pa}$, with a constant frequency of $1 \mathrm{~Hz}$ and frequency sweeps varying from $0.1-10 \mathrm{~Hz}$, constant stress of $0.1 \mathrm{~Pa}$, the complex viscosity $\left(\eta^{*}\right)$ was obtained.

The blends were measured after homogenization and cooling (t0) after 2, 4, 6 and 24 hours of ageing ( $22 \mathrm{~h}, \mathrm{t} 4 \mathrm{~h}$, and $\mathrm{t} 6 \mathrm{~h}, \mathrm{t} 24 \mathrm{~h}$, respectively) at $4{ }^{\circ} \mathrm{C}$.

\section{Ice creams}

After production, the ice creams were all stored at $-20^{\circ} \mathrm{C}$ to finalize the freezing process. Analyses were carried out within 5 days of storage at $-20^{\circ} \mathrm{C}$ to maintain smooth texture of ice cream.

Rheological measurements of frozen products were determined by oscillatory tests by using MARS Rheometer, Haake, cone-plate sensor (C35/2Ti). A Peltier plate controlled the temperature $\left(-8{ }^{\circ} \mathrm{C}\right)$ of the samples during the analyses. Rheometrical measurements of ice cream samples produced for the same processing conditions were replicated thrice. Prior to the frequency test, a deformation amplitude test, from 0.1 to $1000 \mathrm{~Pa}$, at a constant frequency of $0.5 \mathrm{~Hz}$, was carried out at $-8{ }^{\circ} \mathrm{C}$ to determine the linear viscoelastic regime of the formulations and to select the deformation that would be employed in the following analyses to preserve the structure of the samples. The constant deformation amplitude of $30 \mathrm{~Pa}$ was hence chosen for all oscillatory measurements. Such deformation amplitude was established within the linear range, the oscillation frequency was varied between 0.1 to $10 \mathrm{~Hz}$ and the temperature was kept

Table 1. Stabilizers used in formulations.

\begin{tabular}{|c|c|c|c|c|c|c|}
\hline & Test 1 (T1) & Test 2 (T2) & Test 3 (T3) & Test 4 (T4) & Test 5 (T5) & Test 6 (T6) \\
\hline K-carrageenan (\%) & 0.035 & 0.035 & 0.035 & 0.035 & 0.035 & 0.035 \\
\hline Guar Gum (\%) & 0.18 & * & * & 0.09 & * & 0.09 \\
\hline LBG (\%) & * & 0.18 & * & 0.09 & 0.09 & * \\
\hline Gelatin (\%) & * & * & 0.18 & * & 0.09 & 0.09 \\
\hline
\end{tabular}


constant at $-8{ }^{\circ} \mathrm{C}$. The elastic and viscous modulus ( $\mathrm{G}^{\prime}$ and $\mathrm{G}^{\prime}$, respectively) were evaluated as function of frequency.

In the oscillatory thermo-rheometry conducted within the range of linear viscoelasticity, the temperature was continuously increased from $-10{ }^{\circ} \mathrm{C}$ to $5{ }^{\circ} \mathrm{C}\left(0.25{ }^{\circ} \mathrm{C} / \mathrm{min}\right)$ at a constant frequency of $1.592 \mathrm{~Hz}$ (angular frequency $\omega=10 \mathrm{~s}^{-1}$ ) and the mechanical spectra were obtained.

\subsection{Overrun}

Overrun was defined as volume of the mixture, and it was weighed after the ageing process in a $10 \mathrm{~mL}$ glass Beaker. Almost immediately after the freezing and aeration process of the ice cream, the same volume was weighed in the same glass Beaker. The overrun was calculated in triplicate using the equation proposed by Goff \& Hartel (2004) as shown in Equation 1:

$\%$ overrun $=\frac{m_{\text {mixture }}-m_{\text {ice cream }}}{m_{\text {mixture }}} \times 100$

\subsection{Texture}

The determination of the frozen products extrusion force was lead in triplicate in a TA-XT2 (Stable Micro System, UK) with the $\mathrm{AB} / \mathrm{E}$ back extrusion probe ( $4 \mathrm{~cm}$ piston diameter), the cup was filled to about 1 inch from the top for all samples, moving at a speed of $2 \mathrm{~mm} / \mathrm{s}$ and covering $15 \mathrm{~mm}$. The test curves were generated in the program "Texture Expert Exceed" - version 2.6, where the maximum force required to extrude the samples of all the ice cream formulations were determined. It occurred immediately after the aeration and freezing process, where the mass temperature was at $-5^{\circ} \mathrm{C}$.

\subsection{Statistical analysis}

The results obtained by the rheological analyzes were evaluated by ANOVA and Tuckey comparison ( $\mathrm{p}<0.05)$ using the Minitab software (USA).

\section{Results and discussions}

\subsection{Complex viscosity of the mixtures for ice creams}

The viscosity is the quantity that measures the friction between subsequent layers of liquid. Thus, viscous fluids require more force to move than those less viscous. The complex viscosity $\left(\eta^{*}\right)$ gives us a direct relationship between viscosity obtained as a function of frequency. It describes the total resistance to a dynamic shear, pointing the two components - elastic and viscous of the sample.

Table 2 shows the complex viscosity, when $\mathrm{f}=0.1 \mathrm{~Hz}$, to T1, T2 and T3 samples, separated hydrocolloids.

Mixtures produced with Guar gum (T1) and Gelatin (T3) showed no relationship between complex viscosity and the ageing time. The sample produced with LBG (T2) showed significant viscosity increase after 24 hours of ageing.

Table 3 shows the behavior of the complex viscosity for the mixtures during ageing, produced with combinations of these hydrocolloids when $\mathrm{f}=0.1 \mathrm{~Hz}$
Table 2. Complex viscosity $\eta^{\star}$ (Pa.s), in frequency $0,1 \mathrm{~Hz}$, times $\mathrm{t} 0$, $\mathrm{t} 2 \mathrm{~h}, \mathrm{t} 4 \mathrm{~h}, \mathrm{t} 6 \mathrm{~h}$ and $\mathrm{t} 24 \mathrm{~h}$, for separated hidrocolloids.

\begin{tabular}{cccc}
\hline \multicolumn{4}{c}{$\eta^{*}($ Pa.s) } \\
\hline Time (h) & Guar Gum (T1) & LBG (T2) & Gelatin $(T 3)$ \\
\hline $\mathbf{0}$ & $9.769 \pm 0.136^{\mathrm{aA}}$ & $8.558 \pm 0.543^{\mathrm{aB}}$ & $7.295 \pm 1.580^{\mathrm{aB}}$ \\
$\mathbf{2}$ & $29.835 \pm 16.625^{\mathrm{aA}}$ & $7.707 \pm 0.027^{\mathrm{aA}}$ & $8.982 \pm 1.23^{\mathrm{aA}}$ \\
$\mathbf{4}$ & $20.365 \pm 8.075^{\mathrm{aA}}$ & $9.105 \pm 1.162^{\mathrm{aA}}$ & $9.168 \pm 3.148^{\mathrm{aA}}$ \\
$\mathbf{6}$ & $11.139 \pm 1.769^{\mathrm{aA}}$ & $9.006 \pm 0.674^{\mathrm{aAB}}$ & $6.652 \pm 1.941^{\mathrm{aB}}$ \\
$\mathbf{2 4}$ & $18.055 \pm 1.325^{\mathrm{aA}}$ & $12.887 \pm 1.558^{\mathrm{bB}}$ & $10.498 \pm 2.489^{\mathrm{aB}}$ \\
\hline
\end{tabular}

${ }^{*}$ Different lowercase letters indicate significant differences, $\mathrm{p} \leq 0.05$, between different ageing times of the sample (column) and different uppercase letters indicate significant differences, $\mathrm{p} \leq 0.05$, between different samples in the same ageing time (lines).

Table 3. Complex viscosity $\eta^{\star}$ (Pa.s), in frequency $0.1 \mathrm{~Hz}$, times $\mathrm{t} 0$, $\mathrm{t} 2 \mathrm{~h}, \mathrm{t} 4 \mathrm{~h}, \mathrm{t} 6 \mathrm{~h}$ and $\mathrm{t} 24 \mathrm{~h}$, for mixtures of hidrocolloids.

\begin{tabular}{cccc}
\hline \multicolumn{3}{c}{$\eta^{*}($ Pa.s $)$} \\
\hline $\begin{array}{c}\text { Time } \\
(\mathrm{h})\end{array}$ & $\begin{array}{c}\text { Guar Gum+LBG } \\
(\mathrm{T} 4)\end{array}$ & $\begin{array}{c}\text { LBG }+ \text { Gelatina } \\
(\mathrm{T} 5)\end{array}$ & $\begin{array}{c}\text { Guar Gum+ Gelatin } \\
(\mathrm{T} 6)\end{array}$ \\
\hline $\mathbf{0}$ & $10.811 \pm 3.062^{\mathrm{aA}}$ & $2.513 \pm 0.637^{\mathrm{aB}}$ & $3.232 \pm 0.200^{\mathrm{aB}}$ \\
$\mathbf{2}$ & $8.122 \pm 1.631^{\mathrm{aA}}$ & $3.849 \pm 0.177^{\mathrm{abB}}$ & $6.674 \pm 0.761^{\mathrm{abA}}$ \\
$\mathbf{4}$ & $9.628 \pm 0.351^{\mathrm{aA}}$ & $5.701 \pm 0.641^{\mathrm{bB}}$ & $10.977 \pm 2.370^{\mathrm{bcA}}$ \\
$\mathbf{6}$ & $10.423 \pm 0.204^{\mathrm{aA}}$ & $16.723 \pm 1.370^{\mathrm{cB}}$ & $14.053 \pm 4.268^{\mathrm{cA}}$ \\
$\mathbf{2 4}$ & $30.293 \pm 6.123^{\mathrm{bB}}$ & $42.290 \pm 2.813^{\mathrm{dC}}$ & $50.597 \pm 4.617^{\mathrm{dC}}$ \\
\hline
\end{tabular}

${ }^{*}$ Different lowercase letters indicate significant differences, $p \leq 0.05$, between different ageing times of the sample (column) and different uppercase letters indicate significant differences, $\mathrm{p} \leq 0.05$, between different samples in the same ageing time (lines).

The produced mixture with a combination guar gum and LBG (T4) showed a significant increase in viscosity only after 24 hours of ageing. Already mixtures produced with gelatin and LBG (T5) and Gelatin and Guar Gum (T6) showed a strong relationship between complex viscosity and the ageing time.

During low-temperature ageing the physical properties of the emulsions are changed in part due to hydration of the stabilizers, resulting in increased viscosity. Patmore et al. (2003) demonstrated that the present stabilizers in ice cream emulsions alter the rheological properties thereof. The stabilizers which are not frozen in the ice cream phase interact significantly affecting the rheological and textural properties of the product. The presence of non-gelling polysaccharides such as Guar gum and LBG resulting in an increased viscous property of the system much greater than when using gelatin alone.

With increasing frequency, all samples showed significant reduction in complex viscosity (not shown) which can be explained by the breakdown of fat particles present in the emulsion. As can be seen, the viscosity shown by the mixtures depends on the type of hydrocolloid used in the formulation and particle size of the system.

\subsection{Overrun}

The process of freezing and aeration involves numerous physical changes including the action of proteins and surfactants in the formation and stabilization of foam, the partial coalescence 
of fat emulsion and solution concentration due to the freezing of liquid water (Goff \& Hartel, 2004).

The prepared formulations showed values of overrun calculated according to Equation 1, between 33 and 65\%, approximately. The results are shown in Figure 1.

The $\mathrm{T} 2$ formulation produced with $\mathrm{LBG}$, and the formulation $\mathrm{T} 3$, produced with gelatin showed the greatest incorporation of air, around $65 \%$. Already T5 formulation, produced by the combination of these two hydrocolloids showed lower overrun. The combination of Guar Gum with LBG (T4) led to lower overrun between samples, and the formulations produced with each of these separately hydrocolloids, T1 and T2, showed much higher overrun.

This behavior can be explained by the increased viscosity of the system when we combine two hydrocolloids hindering the incorporation of air, can be observed in the complex viscosity results, as well as the results found by Udabage et al. (2005).

The air cells of the structure of the ice creams are essentially spherical, but there are some distortions due to the formation of the network of fat and ice crystals. The material surrounding the air cells is a non-Newtonian fluid containing small particles of fat and ice crystals (Aime et al., 2001; Su \& Lannes, 2012). Thus, the addition of hydrocolloids affects the characteristics of the fluid, and therefore the forming of ice crystals and the formed fat network, and thus the air cells. In industrial lines the system of production of ice cream has injection pumps of predetermined amounts of air or nitrogen gas, so the food can be easily expanded (Lannes \& Silva, 2013).

\subsection{Texture}

The values of the necessary force to samples extrusion are showed in Figure 2.

The ice creams produced with blends of hydrocolloids showed lower force required for extrusion than the ice cream produced with stabilizers alone.

The structural components of ice cream contribute significantly to the formation of the texture of the product. The determination of the texture can be performed by determining the colloidal aspects related to the microstructure of ice creams and the viscoelasticity characteristics of the emulsions and thermal properties. As in the work of Soukoulis et al. (2010), no correlation was found between analytical texture and overrun of the ice cream, it due to side effects, such as ice crystals, for example. Both the size of the ice crystals as the volume of the frozen phase contributes to increased hardness of the ice cream. Although direct correlation between overrun and extrusion force for the samples does not exist, can be noticed a trend of greater force required for extrusion for ice cream with greater incorporation of air.

The results of complex viscosity $\left(\eta^{*}\right)$ of the mixture after 24 hours of ageing, can be correlated with the strength of the extrusion. We noticed that the higher the viscosity of the mixture (formulation T4, T5 and T6), less force was required for extrusion of ice cream after whipping. When the complex viscosity of the mixture after 24 hours of ageing compared with

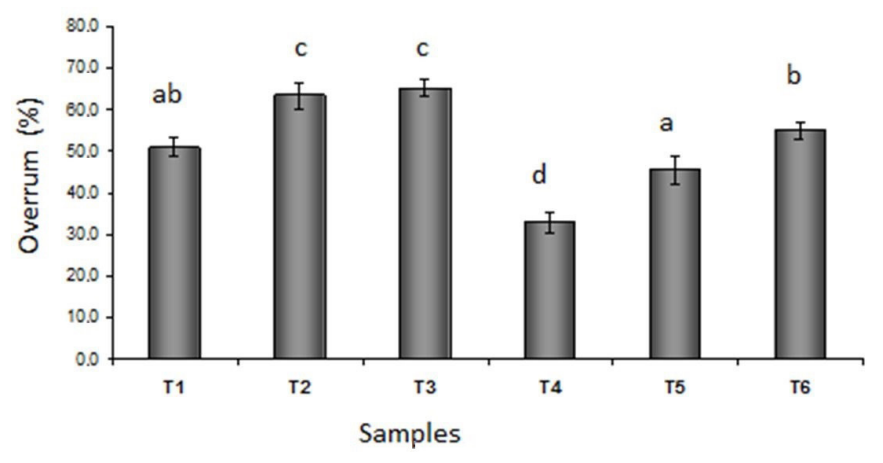

Figure 1. Overrum (\%) in samples T1 - Guar Gum, T2 - LBG, T3 - Gelatin, T4 - Guar Gum + LBG, T5 - LBG + Gelatin, T6 - Guar Gum + Gelatin. Different letters means significative difference between samples $(\mathrm{p} \leq 0.05)$.

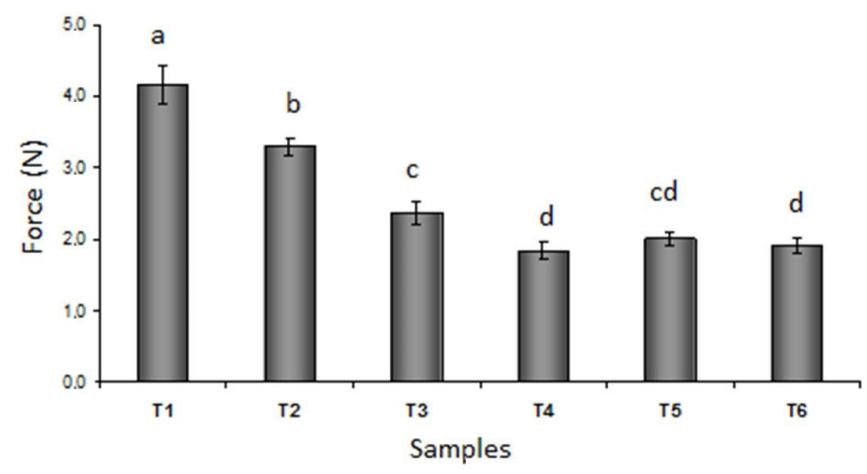

Figure 2. Maximum force to extrude the samples T1 - Guar Gum, T2 - LBG, T3 - Gelatin, T4 -Guar Gum + LBG, T5 - LBG + Gelatin, T6 - Gelatin + Guar Gum. Different letters means significative difference between samples $(\mathrm{p} \leq 0.05)$.

the overrun, realize that formulations showed lower viscosities (T1, T2 and T3), showed higher incorporation of air (overrun). That's because, according Udabage et al. (2005), mixtures of low viscosity facilitating the process of aeration. Aeration is affected by the tendency of the fat globules coalesce under the conditions of stirring and freezing and the skill mix to stabilize the air cells.

\subsection{Frequency sweep test}

The storage modulus (G') and loss (G') were obtained by frequency sweep test from 0.1 to $10 \mathrm{~Hz}$, to $-8^{\circ} \mathrm{C}$, with a stress value within the linear range $(30 \mathrm{~Pa})$.

At low temperatures, the rheological behavior of ice cream is mainly influenced by the ice fraction and by the microstructure. Wildmoser et al. (2004) correlated the ice crystal size, measured by microscopy with the storage modulus and concluded the formulations with lowers ice crystals presented lower G' values. The storage modulus, G', was also correlated with the hardness/stiffness of ice cream, since it represents the solid-body like behavior of the sample tested. In terms of sensory characteristics, the value of G" at low temperatures can be correlated with the flowability and scoopability of the ice cream, important features regarding 
to bombing process during manufacture and handling the product at the sale point (Ikhu-Omoregbe, 2009; Adapa et al., 2000; Wildmoser et al., 2004).

The storage modulus of the ice creams produced with Guar Gum (T1) and with the mixture of this gum with LBG (T4) and with Gelatin (T6) can be observed in Figure 3. At low oscillation frequencies, the ice cream produced with Guar gum only (T1) presented harder texture, indicative of bigger ice crystal than the ice cream produced with the mixture of this hydrocolloid with LBG (T4) and with Gelatin (T6), showing a synergy of two hydrocolloids resulting in different ice cream microstructures. Increasing the frequency, the difference between the products becomes minimal.

The ice cream produced with LBG (T2) presented less rigidity between the samples $\mathrm{T} 2, \mathrm{~T} 3$ and $\mathrm{T} 5$, so easy to handle. The ice cream produced with LBG + Gelatin (T5) is similar to ice cream produced on with gelatin (T3) (Figure 4).

The formulations, T1, T4 and T6, presented very similar behavior for the loss modulus, G", practically independent of the frequency, characteristic of gels (not shown).

The rheology characteristics of the formulations T2 (LBG), T4 (LBG + Guar gum) and T6 (LBG + Gelatin) showed the

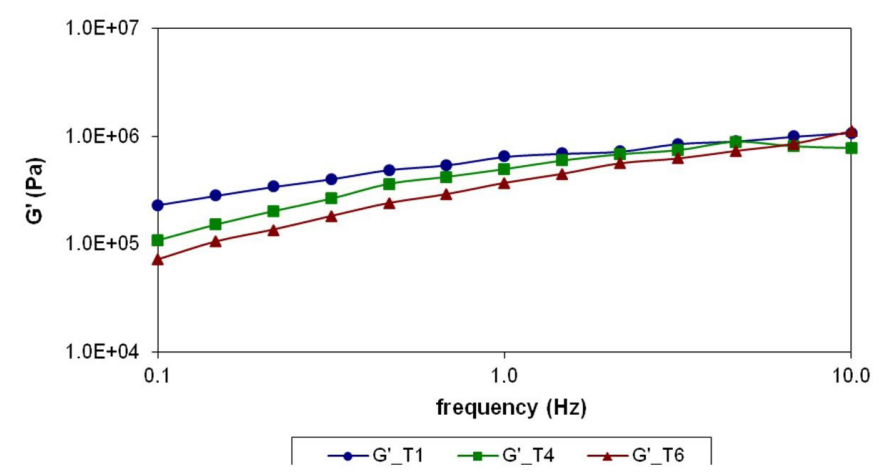

Figure 3. Storage modulus $G^{\prime}$ as function of oscillation frequency measured for the samples produced with Guar Gum (T1 - circles), Guar gum + LBG (T4 - squares) and Guar gum + Gelatin (T6 -triangles).

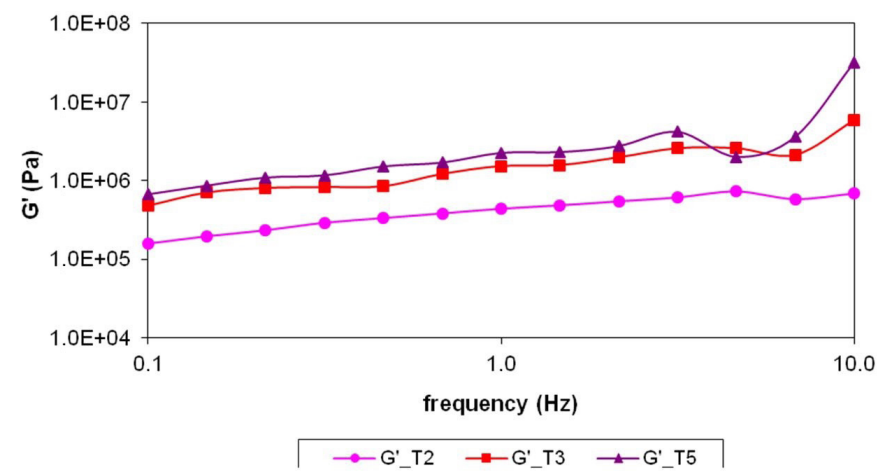

Figure 4. Storage modulus G' as function of oscillation frequency measured for the samples produced with LBG (T2 - circles), Gelatin (T3 - squares) and LBG + Gelatin (T5 -triangles). ice cream produced with LBG only presents lower G' values, characteristic of less hard ice cream and with smaller ice crystals than the ice creams produced with the mixture of LBG with other stabilizer (Figure 5). Observing the loss modulus G", the flowability and scoopability of the ice cream produced with LBG only seemed to be improved in comparison to the other formulations (Figure 6).

\subsection{Oscillatory thermo-rheometry}

When the ice cream is completely frozen, it is expected a maximum storage modulus ( $G^{\prime}$ ) due to the maximum solids ratio. The loss modulus (G') tends to decrease with the temperature elevation due to the reduction of the ice ratio, thus the capacity of ice cream flowing will be increased (Granger et al., 2004).

The rheological behavior of the ice cream produced with Guar Gum (T1), Guar + LBG (T4) and Guar Gum + Gelatin (T6) as function of temperature can be observed in Figure 7.

High G' value at $-10^{\circ} \mathrm{C}$ features rigid and structured products as the ice crystal microstructure governs the rheological behavior. Between -10 and $0{ }^{\circ} \mathrm{C}$ it is observed for all formulations, a large decline in storage modulus. In this temperature range, variations in G' are correlated to: the loss of cooperative interactions between the ice crystals, associated with its melting, resulting in products with lower stiffness; dilution of the unfrozen phase and modification on the microstructure rearrangement (Granger et al., 2004, 2005). Sensorially, a steeper slope indicates the ice cream provides a greater cold sensation during consumption (Wildmoser et al., 2004).

Around $0{ }^{\circ} \mathrm{C} G$ 'reaches a plateau. All ice is melted; only air, fat, proteins and stabilizers will impact on the rheological characteristics and quality of the ice cream. Comparing the rheological behavior of the formulations in test at temperatures above $0^{\circ} \mathrm{C}$, the magnitude of the $\mathrm{G}^{\prime}$ modulus of the formulationT1 (Guar gum) compared to the formulation T4 (Guar gum + LBG) and the formulation T6 (Guar + Gelatin), characterizes clearly a more structured product. Wildmoser et al. (2004) also correlated higher values of G' with ice creams containing smaller air cells size and greater degree of fat globules aggregation.

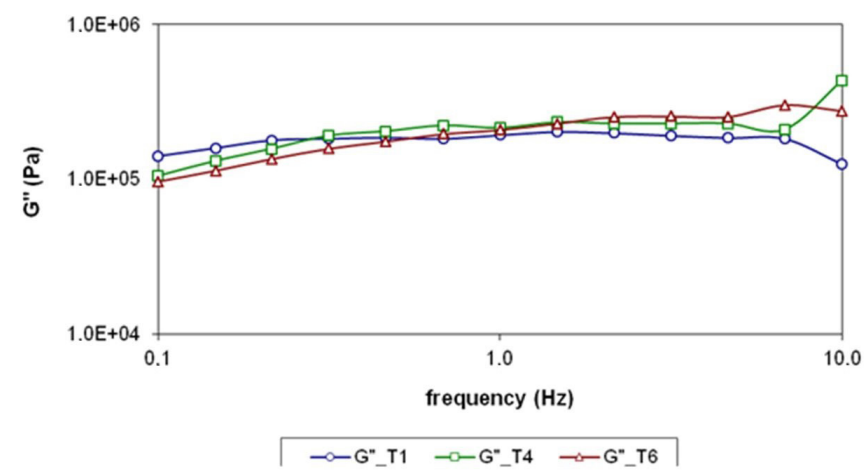

Figure 5. Loss modulus G" as function of oscillation frequency measured for the samples produced with Guar Gum (T1 - circles), Guar Gum + LBG (T4 - squares) and Guar Gum + Gelatin (T6 - triangles). 


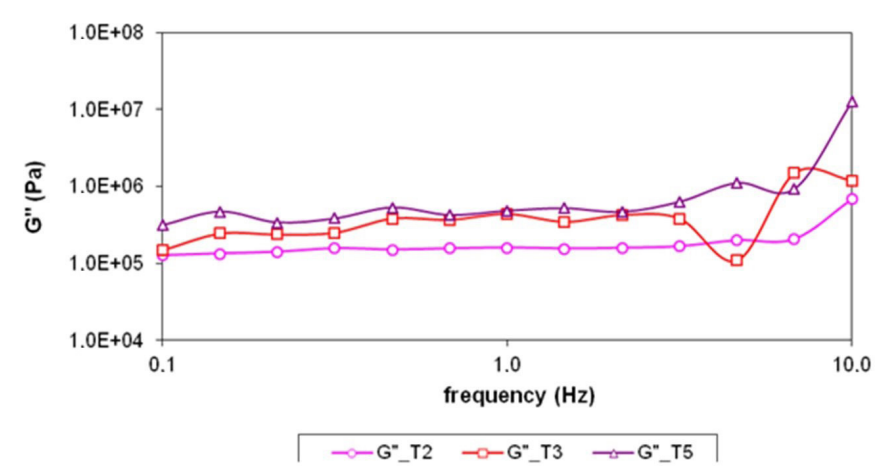

Figure 6. Loss modulus G" as function of oscillation frequency measured for the samples produced with LBG (T2 - circles), Gelatin (T3 - squares) and LBG + Gelatin (T5 -triangles).

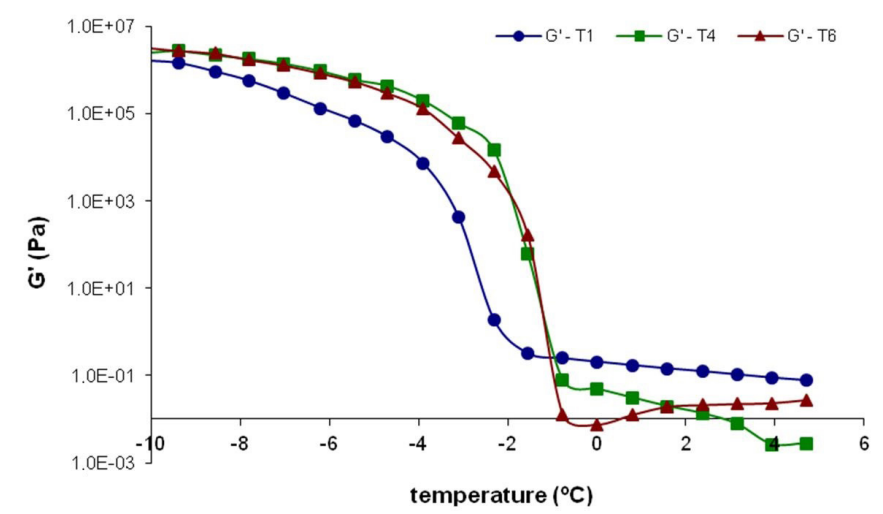

Figure 7. Storage modulus G' as function of temperature measured for the samples produced with Guar Gum (T1 - circles), Guar gum + LBG (T4 - squares) and Guar gum + Gelatin (T6 - triangles).

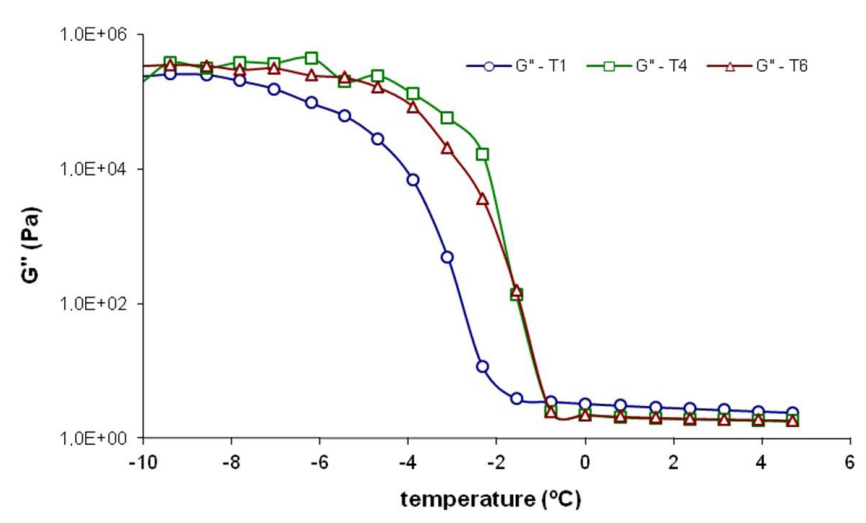

Figure 8. Loss modulus G" as function of temperature measured for the samples produced with Guar Gum (T1 - circles), Guar gum + LBG (T4 - squares) and Guar gum + Gelatin (T6 - triangles).

Above $0{ }^{\circ} \mathrm{C}$, the loss modulus, which describes the viscous behavior and ice cream flow, can be correlated with the creaminess sensation (Wildmoser et al., 2004). The ice cream produced with Guar gum only (T1) presented slightly creaminess than the formulations produced with Guar gum + LBG (T4) and Guar gum + Gelatin (T6) (Figure 8) .

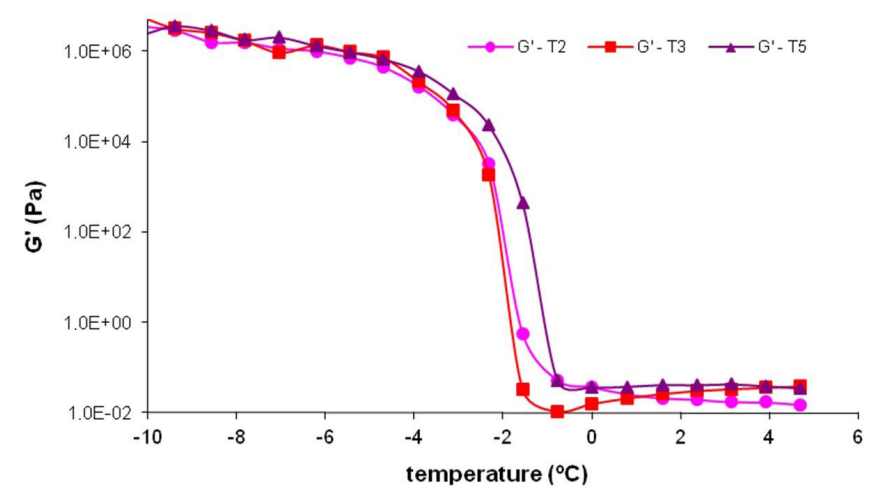

Figure 9. Storage modulus $\mathrm{G}$ ' as function of temperature measured for the samples produced with LBG (T2 - circles), Gelatin (T3 - squares) and LBG + Gelatin (T5 - triangles).

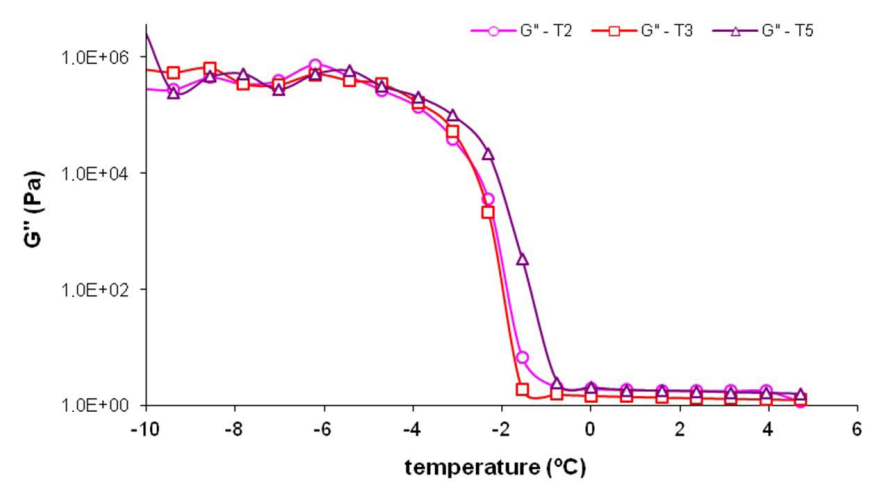

Figure 10. Loss modulus G" as function of temperature measured for the samples produced with LBG (T2 - circles), Gelatin (T3 - squares) and LBG + Gelatin (T5 - triangles).

The Figures 9 and 10 present the rheological behavior in function of the temperature to the ice creams produced with the stabilizers LBG (T2), Gelatin (T3) and LBG + Gelatin (T5).

At very low temperatures, the rheological parameters are influenced primarily by the ice crystals present, so just little variation in the parameters G' and G' were observed until $-4{ }^{\circ} \mathrm{C}$. The ice cream produced with these stabilizers showed very similar rheological behavior.

\section{CONCLUSION}

The oscillatory rheometry can be applied effectively as a tool for sensory and quality evaluation of different ice cream formulations.

The frequency sweep test, performed at $-8^{\circ} \mathrm{C}$, showed lower values of $G^{\prime}$ to the ice cream produced with Gelatin + Guar gum as stabilizer agent, which is an indicative of the presence of smaller ice crystals and higher softness.

Through oscillatory thermo-rheology, between -10 to $5^{\circ} \mathrm{C}$, it was possible to evaluate the changes in the structure of the different ice creams and their relation to the sensory properties. Between $-10^{\circ} \mathrm{C}$ and $-1{ }^{\circ} \mathrm{C}$ it was observed, for all formulations, a 
large decline in the elastic and viscous moduli due to the loss of the cooperative interactions between the ice crystals, associated with their melting. After melting, the formulations did not vary much with respect to the parameter G", which is related to the creaminess of the ice cream during consumption, however it was noted that the ice cream produced with Guar gum presented a slight advantage over the creaminess attribute.

\section{ACKNOWLEDGEMENTS}

To Gelita-Brazil and CAPES-Coordenação de Aperfeiçoamento de Pessoal de Nível Superior.

\section{References}

Adapa, S., Dingeldein, H., Schmidt, K. A., \& Herald, T. J. (2000). Rheological properties of ice cream mixes and frozen ice creams containing fat and fat replacers. Journal of Dairy Science, 83(10), 2224-2229. http://dx.doi.org/10.3168/jds.S0022-0302(00)75106-X. PMid:11049062.

Aime, D. B., Arntfield, S. D., Malcolmson, L. J., \& Ryland, D. (2001). Textural analysis of fat reduced vanilla ice cream products. Food Research International, 34(2-3), 237-246. http://dx.doi.org/10.1016/ S0963-9969(00)00160-5.

Bahramparvar, M., Razavi, S. M. A., \& Khodaparast, M. H. H. (2010). Rheological characterization and sensory evaluation of a typical soft ice cream made with selected food hydrocolloids. Food Science \& Technology International, 16(1), 79-88. http://dx.doi. org/10.1177/1082013209353244. PMid:21339124.

Botega, D. C., Marangoni, A. G., Smith, A. K., \& Goff, H. D. (2013a). The potential application of rice bran wax oleogel to replace solid fat and enhance unsaturated fat content in ice cream. Journal of Food Science, 78(9), C1334-C1339. http://dx.doi.org/10.1111/17503841.12175. PMid:24024686.

Botega, D. C., Marangoni, A. G., Smith, A. K., \& Goff, H. D. (2013b). Development of formulations and processes to incorporate wax oleogels in ice cream. Journal of Food Science, 78(12), C1845-C1851. http://dx.doi.org/10.1111/1750-3841.12248. PMid:24329951.

Faria-Tischer, P. C. S. (2006). Estrutura química, propriedades reológicas e atividade antiviral das galactanas sulfatadas das Algas Vermelhas Meristiella gelidium e Gymnogongrus griffithsiae (Gigartinales). Curitiba: Universidade Federal do Paraná.

Goff, H. D., \& Hartel, R. (2004). Ice cream and frozen desserts. In Y. H. Hui, I. G. Legarretta, M. H. Lim, K. D. Murrell \& W. K. Nip. Handbook of frozen foods (pp. 429-500). United States: CRC Press.

Granger, C., Langendorff, V., Renouf, N., Barey, P., \& Cansell, M. (2004). Short communication: impact of formulation on ice cream microstructures: an oscillation thermo-rheometry study. Journal of Dairy Science, 87(4), 810-812. http://dx.doi.org/10.3168/jds.S00220302(04)73224-5. PMid:15259214.

Granger, C., Leger, A., Barey, P., Langendorff, V., \& Cansell, M. (2005). Influence of formulation on the structural networks in ice cream. International Dairy Journal, 15(3), 255-262. http://dx.doi.org/10.1016/j. idairyj.2004.07.009.
Ikhu-Omoregbe, D. (2009, Aug 23-27). Comparison of sensory qualities of ice cream from rheological characterization. In World congress of chemical engineering - WCCE8. Montréal: Canadian Society for Chemical Engineering.

Kaleda, A., Tsanev, R., Klesment, T., Vilu, R., \& Laos, K. (2018). Ice cream structure modification by ice-binding proteins. Food Chemistry, 246, 164-171. http://dx.doi.org/10.1016/j.foodchem.2017.10.152. PMid:29291835.

Lannes, S. C. S., \& Silva, E. Jr. (2013). Viscoelastic properties of mixtures for ice cream. In G. Mitchell (Org.), Rheology: theory, properties and practical applications (pp. 1-27). New York: Novapublishers.

Muse, M. R., \& Hartel, R. W. (2004). Ice cream structural elements that affect melting rate and hardness. Journal of Dairy Science, 87(1), 1-10. http://dx.doi.org/10.3168/jds.S0022-0302(04)73135-5. PMid:14765804.

Patmore, J. V., Goff, H. D., \& Fernandes, S. (2003). Cryo-gelation of galactomannans in ice cream model systems. Food Hydrocolloids, 17(2), 161-169. http://dx.doi.org/10.1016/S0268-005X(02)00048-6.

Rinaldi, M., Dall'asta, C., Paciulli, M., Guizzetti, S., Barbanti, D., \& Chiavaro, E. (2014). Innovation in the Italian ice cream production: effect of different phospholipid emulsifiers. Dairy Science \& Technology, 94(1), 33-49. http://dx.doi.org/10.1007/s13594-013-0146-1.

Silva, E. Jr., \& Lannes, S. C. S. (2011). Effect of different sweetener blends and fat types on ice cream properties. Food Science and Technology (Campinas), 31(1), 217-220. http://dx.doi.org/10.1590/ S0101-20612011000100033.

Soukoulis, C., Rontogianni, E., \& Tzia, C. (2010). Contribution of thermal, rheological and physical measurements to the determination of sensorially perceived quality of ice cream containing bulk sweeteners. Journal of Food Engineering, 10(4), 634-641. http:// dx.doi.org/10.1016/j.jfoodeng.2010.05.012.

Stanley, D. W., Goff, H. D., \& Smith, A. K. (1996). Texture-structure relationships in foamed dairy emulsions. Food Research International, 29(1), 1-13. http://dx.doi.org/10.1016/0963-9969(95)00063-1.

Su, F., \& Lannes, S. C. S. (2012). Rheological evaluation of the structure of ice cream mixes varying fat base. Applied Rheology (Lappersdorf, Germany), 22, 63871-63877.

Udabage, P., AnnAugustin, M., Cheng, L. J., \& Williams, R. P. W. (2005). Physical behaviour of dairy ingredients during ice cream processing. Le Lait, 85(4-5), 383-394. http://dx.doi.org/10.1051/lait:2005025.

Wildmoser, H., Scheiwiller, J., \& Windhab, E. J. (2004). Impact of disperse microestructure on rheology and quality aspects of ice cream. Food Science and Technology-LWT, 37(8), 881-891. http:// dx.doi.org/10.1016/j.lwt.2004.04.006.

Winhab, E. J. (1993). Feinkost und speiseeis. In: D. Weipert, H. D. Tescheuschner, \& E. J. Winhab (Eds.), Rheologie der lebensmittel. Hamburg: Behr's Verlag.

Zhao, Q., Kuang, W., Fang, M., Sun-Waterhouse, D., Liu, T., Long, Z., \& Zhao, M. (2015). Frozen, chilled and spray dried emulsions for whipped cream: Influence of emulsion preservation approaches on product functionality. Food Science and Technology-LWT, 62(1), 287-293. http://dx.doi.org/10.1016/j.lwt.2014.06.024. 